\title{
Planning Interface for Social Service Delivery between Local Government Authorities and Corporates in Morogoro, Tanzania
}

\author{
Angela Jesse \\ Department of Development Studies \\ College of Social Sciences and Humanities \\ Sokoine University of Agriculture \\ P.O. Box 3024, Morogoro, Tanzania \\ Kenneth M.K. Bengesi \\ Department of Policy Planning and Management \\ College of Social Sciences and Humanities \\ Sokoine University of Agriculture \\ P.O. Box 3035, Morogoro, Tanzania
}

\begin{abstract}
Drawing from Communicative Planning Theory (CPT), this paper examined planning interface for social service delivery between Local Government Authorities (LGA) and Corporates in Morogoro region using a case study design. Results revealed that LGAs planning process was inclusive and transparent enabling corporates to decide on kind of services to provide to communities. Conversely, Mtibwa Sugar Company was not transparent to share their planning decisions with the LGA whereas Kilombero Sugar Company was transparent in sharing their planning decisions to the LGA. Hence, LGAs planning processes are in line with CPT, which considers inclusiveness and transparent as core components for effective planning. The findings further revealed misalignment of planning seasons between the LGAs and corporates leading to double allocation of resources for some social services. The study recommends that there should be budget review by the LGA to relocate resources that corporates use to support community activities.
\end{abstract}

Keywords: Planning, inclusiveness, transparency, social services, corporate, Local Government Authorities

\subsection{Introduction}

Literature on planning presents Local Government Authorities (LGAs) as key actors responsible for provision of social services in areas of their jurisdiction (Komba et al., 2018; Boris, 2015; Iravo and Nzulwa, 2015). One of the LGAs' major objectives is to transfer the authority over planning and implementation of development programs to people (Bengesi, 2014; Bengesi et al., 2009; Komba et al., 2018; Ejue, 2014). In rendering social services, LGAs use various sources of finances such as their own source, fund from the central government and donors (Lunyelele et al., 2016; Henjewele et al., 2004). Despite these various sources, LGAs still face shortage of funds for providing social services. Thus, other development stakeholders from public and private sectors, including corporate contribute to the LGAs mandate of rendering social services to communities (Bengesi et al., (2016).

Corporates, including sugar companies, on the other hand tend to seek acceptability and trust of communities which includes their employees and consumers of their products (Caroll and Shabana, 2010; Aguinis and Glavas, 2012; Revathy, 2012; Abdulillah et al, 2017). In order to achieve this end, companies through Corporate Social Responsibility (CSR) provide social services by giving back part of their profit. Most scholars argue that CSR integrates broader societal concerns into business strategy and that through CSR; corporates offer social services to communities, which could have been offered by LGAs (Hohnen, 2007; Crowther and Aras, 2008; Smith, 2011; O'riordan and Fairbrass, 2014).

In this regard, scholars have sought to establish approaches used by the LGAs in guiding the planning process at the local level including involvement of local communities in identifying their needs and priorities (Maliganya and Bengesi, 2018; Lunyelele et al., 2018; Chirenje, 2013). However, scholars have paid little attention to the interface of planning for social service delivery between LGAs and other development stakeholders including corporates. Such interface could help in avoiding the possibility of duplication of efforts in provision of social 
services, which leads to wastage of resources. A planning interface for social service delivery according to this study is a situation where actors, particularly LGAs and corporates interact for the aim of engaging each other in the planning process. As such, the interaction between the LGAs and corporates is likely to inform the LGAs on which responsibilities of the social services are to be offered by the corporates and take into account for this contribution in their budget and be able to use optimally the scarce available resources to the neediest areas.

While it is compelling to believe that this is one of the appropriate ways of efficient utilization of resources, little is known on how the LGAs interact with corporates during the planning process. Therefore, this paper seeks to fill the knowledge gap by assessing the planning interface between LGAs and corporates. The rest of the paper contains theoretical framework where concepts of the study are framed. Methodology is another part, which consists of the description of the study area, research design and data sources, data collection method and tools, and method for data analysis. The study further includes results and discussion, which discusses how LGAs and corporates involve each other to the planning for social service delivery and how they openly share the planning decisions. The last part is conclusion and recommendation.

\subsection{Theoretical Framework}

This study was guided by the Communicative Planning Theory (CPT), which builds upon Jurgen Habermas idea of communicative rationality. This theory emphasizes on inclusiveness and transparency in the communication process among stakeholders (Elliott, 2014) and it enables the concepts to indicate the interface between stakeholders in planning process. According to the theory, inclusiveness and transparency are the core components of planning process, which lead to successful outcomes (Healey, 2006). Inclusiveness and transparency are among key principles of planning (Agba et al., 2013; Litman, 2013). Planning process is inclusive and transparent when it touches the interests of a broad range of stakeholders (Weston and Weston, 2013). According to CPT, inclusiveness in the planning process is observed by involving a range of stakeholders on matters that affect them. In addition, inclusiveness implies an opportunity to people affected by the plan to be involved in the planning process (Ringold et al., 2012; Healy et al., 2014).

On the other hand, transparency in planning can be viewed when the planning process is open and stakeholders are informed of all major decisions made during the process (Johnston, 2002). The theory emphasize on transparency as central to achieve legitimacy and trust in any planning system. Other authors suggest that transparency indicates that individuals involved in the planning process understand how the process operates and how major decisions are arrived (Agba et al., 2013; Muhammad et al., 2015; Komba et al., 2018). The current paper focuses on both inclusiveness and transparency; in this context inclusiveness implies the extent of stakeholders involvement in the planning process while the transparency suggest the openness of the major decisions made during the planning process to the key stakeholders.

The CPT upholds inclusiveness and transparency because the selection of means in the planning process cannot be isolated from the identification of valued ends of various stakeholders (Healey, 2006). Thus, planning is not the pre-occupation of planners only but concerns other stakeholders too. With respect to this study, the planning interface between LGAs and corporates is a means of avoiding duplication of social services, which at the end translates into wastage of resources. The interface also results in complementing of resources when planning for social services delivery. Lastly, the interface enables acceptance and acknowledgement of services provided to communities. In this case, the study on planning interface between the LGAs and corporates for social service delivery is justified.

\subsection{LGAs' planning process}

The literature on planning indicates the relevance of involvement of community members in planning for social service delivery specifically in identifying and making decisions on kind of social services to be provided to communities (Maliganya and Bengesi, 2018; Chirenje, 2013; Komba et al., 2018). Development practitioners in Tanzania assume that planning tool known as Opportunities and Obstacles to Development (O\&OD), which is used in planning for social services delivery at the local level, ensures the involvement of community members (Mefunya, 2011; Balato and Ibrahim, 2012). According to Fjeldstad et al. (2010), the planning process for social service delivery through O\&OD is usually scheduled to be carried out over a period of twelve days as described in Table 1. 


\section{Table 1: Twelve days for executing O\&OD in Tanzania}

\begin{tabular}{|c|c|c|}
\hline Day & Rural & Urban \\
\hline One & $\begin{array}{l}\text { Social preparation and secondary data } \\
\text { collection }\end{array}$ & Social preparation and secondary data collection \\
\hline Two & $\begin{array}{l}\text { Social preparation and secondary data } \\
\text { collection }\end{array}$ & Social preparation and secondary data collection \\
\hline Three & $\begin{array}{l}\text { Extraordinary village assembly to launch } \\
\text { O\&OD; } \\
\text { formation of focus group (FG), selection of } \\
\text { map drawers and community resource persons, } \\
\text { and primary data collection }\end{array}$ & $\begin{array}{l}\text { Zonal/street meeting to launch O\&OD; } \\
\text { formation of focus group, selection of map drawers } \\
\text { and community resource persons, and primary data } \\
\text { collection }\end{array}$ \\
\hline Four & $\begin{array}{l}\text { Primary data collection and use of participatory } \\
\text { rural appraisal (PRA) tools }\end{array}$ & $\begin{array}{l}\text { Primary data collection and use of participatory rural } \\
\text { appraisal (PRA) tools }\end{array}$ \\
\hline Five & $\begin{array}{l}\text { Focus group discussions (FGDs) on TDV } \\
2025 \text { 's first principal objective: 'high quality of } \\
\text { livelihood'. Topics: food } \\
\text { self-sufficiency and food security, universal } \\
\text { primary education, gender equality and access } \\
\text { to primary health }\end{array}$ & $\begin{array}{l}\text { Focus group discussions (FGDs) on TDV } 2025 \text { 's first } \\
\text { principal objective: 'high quality of livelihood'. Topics: } \\
\text { food } \\
\text { self-sufficiency and food security, universal primary } \\
\text { education, gender equality and access to primary health }\end{array}$ \\
\hline Six & $\begin{array}{l}\text { Further FGDs on TDV } 2025 \text { 's 'high quality of } \\
\text { livelihood'. Topics: access to reproductive } \\
\text { health, infant and maternal } \\
\text { mortality rates, access to safe water, life } \\
\text { expectancy and abject poverty }\end{array}$ & $\begin{array}{l}\text { Further FGDs on TDV } 2025 \text { 's 'high quality of } \\
\text { livelihood'. Topics: access to reproductive health, } \\
\text { infant and maternal } \\
\text { mortality rates, access to safe water, life expectancy } \\
\text { and abject poverty }\end{array}$ \\
\hline Seven & $\begin{array}{l}\text { FGD on TDV 2025's second and third } \\
\text { principal objectives: 'good governance' and } \\
\text { 'rule of law' }\end{array}$ & $\begin{array}{l}\text { FGD on TDV } 2025 \text { 's second and third principal } \\
\text { objectives: 'good governance' and 'rule of law' }\end{array}$ \\
\hline Eight & FG to prepare draft community plan & FG to prepare draft ward plan \\
\hline Nine & $\begin{array}{l}\text { Village council prioritizes all specific } \\
\text { objectives and drafts three-year community } \\
\text { plan }\end{array}$ & $\begin{array}{l}\text { Zonal/street meetings to discuss and comment on the } \\
\text { draft ward plan }\end{array}$ \\
\hline Ten & $\begin{array}{l}\text { Ward Development Committee (WDC) } \\
\text { meeting provides technical advice on the draft } \\
\text { plan }\end{array}$ & $\begin{array}{l}\text { Focus group under Ward Executive Officer (WEO) } \\
\text { incorporates comments from street meeting into draft } \\
\text { ward development plan }\end{array}$ \\
\hline Eleven & $\begin{array}{l}\text { Extraordinary village assembly to receive and } \\
\text { approve community plans }\end{array}$ & $\begin{array}{l}\text { WDC to priorities all specific objectives, prepare and } \\
\text { endorse the three-year ward plan }\end{array}$ \\
\hline Twelve & $\begin{array}{l}\text { Preparation of simple format by sector at Ward } \\
\text { level. }\end{array}$ & Preparation of simple format by sector at Ward level. \\
\hline
\end{tabular}

Source: Fjeldstad et al. 2010

Although the O\&OD is seen as a tool, which ensures involvement of community members in planning for social service delivery, some literature observe weaknesses in it. Some of these weaknesses are failure of district and ward facilitators to elaborate policy issues, insufficient explanation about monitoring and evaluation, lack of knowledge of how to incorporate community plans into LGAs plan as well as inefficient pre-visit to Villages/Wards (Lunyelele et al., 2016; Mefunya, 2011). Moreover, experiences of practicing O\&OD in Tanzania reveal delays in receiving guidelines and budget ceilings for review of the performance of the previous financial year as well as recapitulating sector policies and areas which are in accordance with the overarching priorities of NSGPR and Vision 2025 from district councils (Fjeldstad et al., 2010, Mefunya, 2011).

According to Fjeldstad et al. (2010), neither the villages nor the wards receive indicative budget figures from the council. Hence, the villages prepare plans according to their needs without any reference to the budgets. Existing literature pays little attention on assessing the involvement of other development partners including corporates in LGAs planning process. The involvement of other development stakeholders like corporates is important because corporates are affected by LGAs plan at the same time through CSR they assist in fulfilling the LGAs mandates of rendering social services to communities. In this view, this study aims at filling the existing knowledge gap by answering the following question on: 


\section{1) How do the LGAs involve corporates in the planning process?}

The answers to this question will provide suggestions to the LGAs regarding the interface between corporates and other development stakeholders in the planning for social service delivery. This will help LGAs to effectively allocate resources based on community needs and eventually avoid duplicating efforts that lead to the wastage of resources.

\subsection{Corporates Planning Process}

Corporate have different ways of planning for social service delivery. Hohnen (2007) upholds that there is no 'one size that fits all' method for implementing CSRs. Planning process for the implementation of CSR depends on the leadership style within companies, companies' policies, companies' objectives, and culture and values of the community in which corporates operate. There are different models, which are used by different companies to execute CSR. For example, Smith (2008) developed a CSR implementation model, which is plan, do, check and improve as described in Table 2:

Table 2:CSR planning model

\begin{tabular}{|c|c|c|}
\hline Items & Explanation & Activities \\
\hline Plan & Organizational responsibility & $\begin{array}{l}\text { - Identify the preferred and decentralized working system } \\
\text { - Clearly defined instructions, instruments and approach in preparation of } \\
\text { phase } \\
\text { - } \quad \text { Asking questions like where we are going and where we are now }\end{array}$ \\
\hline Do & Actions & $\begin{array}{l}\text { - } \quad \text { Conduct a CSR business plan (can be integrated with the organizational } \\
\text { - } \quad \text { Poal or separated) } \\
\text { - } \quad \text { Prepare a CSR commitment draft } \\
\text { - } \quad \text { Consulting working group } \\
\text { - } \quad \text { Set clear responsibility and assignments } \\
\text { - } \quad \text { Setting measurable targets and identify performance } \\
\text { - } \quad \text { Prepare a communication plan }\end{array}$ \\
\hline Check & Evaluate & $\begin{array}{l}\text { - } \quad \text { Measure the targets and recognize performance } \\
\text { - }\end{array}$ \\
\hline Improve & Analyzing & - $\quad$ Strengths, weaknesses, opportunities and threats \\
\hline
\end{tabular}

Source: Smith (2008)

Apart from the above model, Ackerman proposed a model, which was laid down in three phases (Kanji and Agrawa, 2016). The first phase refers to the top managers recognizing a social problem, the second phase involved an intensive study of the problem and finding out solutions by hiring experts and the last phase was implementation of the proposed solutions. However, there is no stage in the mentioned models where other actors such as LGAs with a mandate to deliver social services to communities are involved to the planning for CSR execution. This may result in wastage of resource specifically when the LGAs allocate resources to the service which has already been attended by corporates. This create a gap which needs to be filled by finding out how the planning for CSR executions are linked up to LGAs planning process in events where corporates offers services that could otherwise be rendered by the LGAs. Hence the question rises on:

\section{2) In which ways do corporates involve the LGAs in planning for CSRs in the study area?}

The answer to this question will help to show the importance of corporates involving LGAs in the planning process. Through such engagement, LGAs will identify social services to be rendered by corporates and restructure their budget to put more emphasis on services, which have not been funded by any other development partners.

\subsection{Transparency in LGAs Planning Process}

Most literature termed transparency as openness or disclosure of information (Bengesi and Abdalla, 2018; Hollyer, 2011; Weston and Weston, 2013; Elliott, 2014; Mukhopadhyay, 2017). It is a two way flow of information which is operationalized through public involvement in decision making when planning for social service delivery. Transparency ensures that stakeholders' interest are heard and considered when deciding on the social services to deliver to communities (Carlitz, 2013). The concept of transparency ensures clarity of issues among stakeholders during Planning (Hollyer, 2011). Literature on the LGAs planning for social service delivery 
emphasizes in involving community members in decision making regarding the social services to be implemented to communities (Lunyelele et al., 2018; Smith, 2008; Fjeldstad et al., 2010; Chirenje, 2013). Although transparency is crucial when planning for social service delivery, it is yet not clear to whether the LGAs are transparent in their key decisions to other stakeholders like corporates who support social service delivery initiatives through CSR. This raises another question on:

3) How are LGAs open to share the key/ major planning decisions with corporates?

The answer to this question will provide information on the importance of LGAs sharing information with other stakeholders in and outside Tanzania.

\subsection{Transparency in corporate planning process}

Literature reveals that communities and the LGAs are stakeholders and beneficiaries of CSR performed by corporates (Safkaur, 2016). However, it is reported that the decision making on CSR execution is done by the corporates management alone (Smith, 2008; Kanji and Agrawa, 2016). There is little (if any) information on how corporates share their key planning decisions concerning CSR with LGAs who are mandated to deliver social services to communities. This creates a gap which needs to be filled by this paper through answering the following question on

4) How are corporates open to share the major/key planning decision making with LGAs?

The answer to this question will disseminate information to other corporates on the importance of sharing the key planning decisions on CSR to LGAs who are legally mandated to deliver social services to communities.

According to CPT, an inclusiveness and transparent in planning process are associated with well-informed and socially desirable outcomes. In this case, the study is also aiming at answering the following question:

5) What is the outcome of inclusiveness and transparency in LGAs and corporates planning for social service delivery?

\subsection{Conceptual Framework}

The study's conceptual framework in Figure 1 shows the planning interface between LGAs and corporate for social services delivery. Such interface occurs when there is inclusiveness and transparency as core components of the planning process. Inclusiveness is operationalized by type of stakeholders involved. The assumption is that the LGAs planning process involve stakeholders such as community members and sugar companies among other corporates in the planning process. On the other hand, it is assumed that corporates/companies involve LGAs in the planning to ensure that they understand what support companies are planning to offer to communities. In this study, transparency is noted by evidence of openness of stakeholders in making planning decisions. The nature of inclusiveness and transparency in the planning has implication on how social services are delivered to the communities and ensures accountability of resources from each partner involved in the social service delivery. Finally, inclusiveness and transparency in planning for social service delivery avoid duplication of efforts, which results into wastage of resources. 
Figure 1: Conceptual Framework of the Study

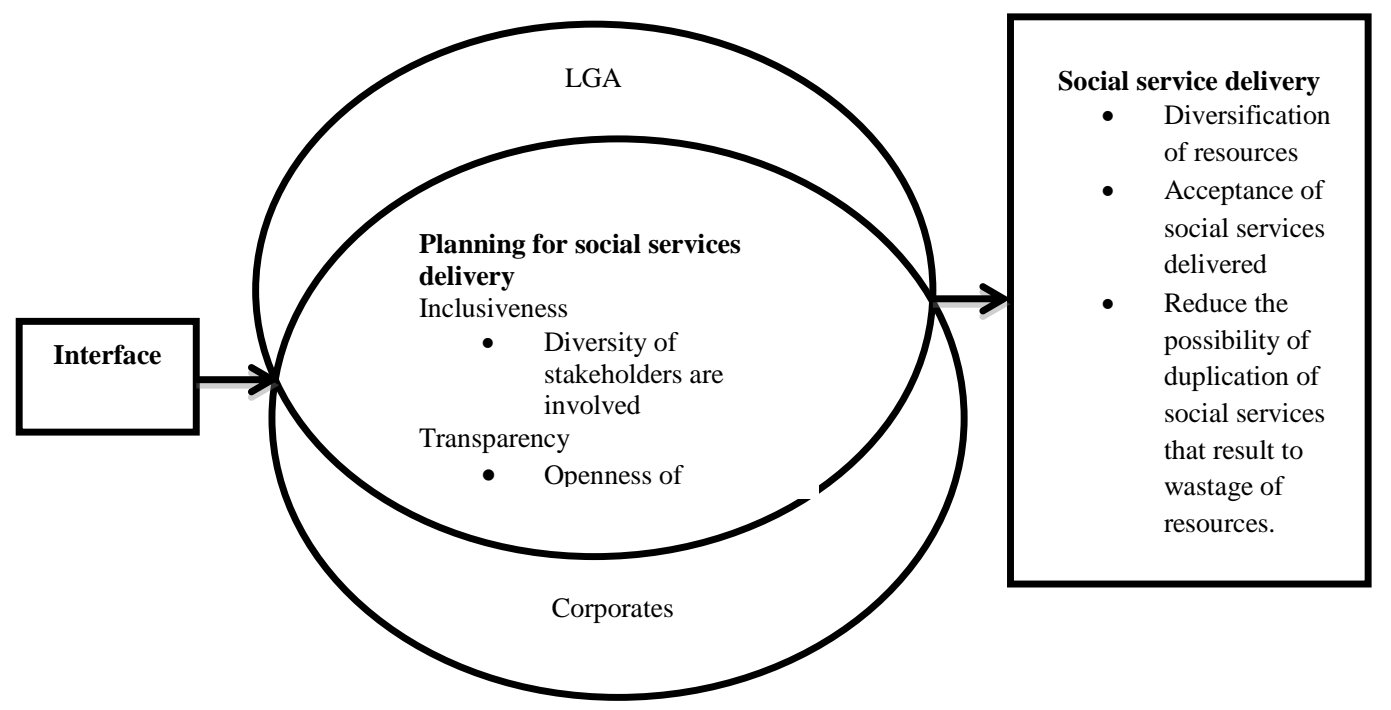

\subsection{Methodology}

\subsection{Description of the Study Areas}

The study involved Kilombero and Mvomero district councils in Morogoro region. Morogoro region was purposely selected because of having two sugar companies. Mtibwa Sugar Company which is locally owned is located in Mtibwa ward of the Mvomero district and Kilombero Sugar Company which is a multinational company found in Kidatu Ward of Kilombero district. Despite the ownership, the two companies situated in the same region are producing the same product. Therefore, it was necessary to explore how each of the companies contributes to social service delivery through CSR.

\subsection{Research Design and Data Sources}

The study adopted a case study design because it involve four cases including two LGAs and two sugar companies. The case study design provides tools for researchers to study complex phenomena within their contexts (Baxter, 2008; Starman, 2013). Four villages, including Mkamba and Msolwa station in Kidatu Ward and Madizini and Kidudwe in Mtibwa Ward were purposively selected based on the presence of social services provided by Kilombero and Mtibwa sugar companies and the respective LGAs. Sources of data constitute key informants from District councils, sugar companies, and ward and village councils. Key informants were purposively selected and constituted Chief Executive Officers, District Executive Directors, Ward Executive Officers, Ward Councilors, Heads of Departments in councils, Village Executive Officers, Community Development Officers, village chair persons, health officers at the districts and wards. Also participants of Focus Group Discussion (FGD) were used to get data. Simple random sampling was employed to select participants of FGD from village councils.

\subsection{Data Collection Method and Tools}

The interview guide was used to gather information from key informants and FGD. This method enables the researcher to collect in-depth qualitative information. Face to face and telephone conversation were used whereby, face to face interviews were conducted at first sight then phone calls were used to fill information gaps observed during data transcription. The data were collected from key informants and FGD for triangulation purpose.

\subsection{Data Analysis}

Conventional content analysis was used to analyze data obtained from key informants and focus group discussions. Data collected through recording were transcribed prior to data analysis. Different categories such as involvement of LGAs and corporates to their planning process for social services and openness in sharing planning decisions were labeled. Categories with the same codes were linked in a logical and meaningful organization. Then a single core category was identified.

\subsection{Results and Discussion}


This paper examined planning interface between LGAs and sugar companies for social services delivery. Specifically, the paper examined inclusiveness and transparency in LGAs and corporates planning processes. The discussion is responding to the following questions; how do LGAs involve corporates in the planning process? In which ways do corporates involve LGAs in planning for CSRs? How LGAs are open to share major/key planning decisions with corporates? How are corporates open to share major/key planning decision making with LGAs? And what is the outcome of inclusiveness and transparency in LGAs and corporates planning processes?

\subsection{Planning Process for Social Service Delivery}

This paper examined the planning process for both LGAs and corporates with the emphasis on how inclusiveness and transparency is exercised in the course of planning. In view of the fact that LGAs and corporates have different orientation in fulfilling their mandated activities, it is evident that corporates through CSR offers social services which in a way complement social services which could otherwise be offered by LGAs. In this context, one will expect the two organizations to have a synergy during planning process to avoid duplication of efforts that leads to the wastage of resources. Looking this way, it was compelling to critically examine the planning process of each part and see if there is any involvement and transparency between LGAs and corporates.

\subsubsection{Engagement of Corporates in LGAs Planning Process}

The paper assessed how stakeholders including corporates are involved in LGAs planning process in the study area. Results in Table 3 revealed different approaches of planning process from two Wards in different district councils (Kidatu Ward in Kilombero and Mtibwa Ward in Mvomero). Planning process in Mtibwa Ward commence at the Village Council (VC) in which the community needs are identified. Community members are represented by the hamlet leaders and other representatives from different groups such as the elderly, women and disabled to the VC. Identified needs in the VC are presented to the Village Assembly (VA) for discussion and selection of priorities. In Kidatu Ward the needs are identified by the community members at the hamlet level, and then the $\mathrm{VC}$ combines the identified needs and presents them to the VA for discussion and prioritizing the community needs. The planning processes at Kidatu and Mtibwa Wards match in preparing the Ward development plans where other stakeholders including Kilombero and Mtibwa Sugar Companies are invited in Ward Development Committee (WDC). It is in the WDC where development stakeholders including sugar companies get to know the community priorities. For example, it was reported that,

"...the aim of inviting other stakeholders is for them to know our plans and assist us in some of community needs" (Key informant 3, Kidatu Ward, Kilombero district, August, 2015).

This quote provides evidence of inclusiveness because other stakeholders including corporates and the community members are involved in the planning process. The results are in line with Communicative Planning Theory, which emphasize that a planning process is inclusive when a broad range of stakeholders is involved to the planning process. In line to this argument other scholars have argued that inclusiveness is all about each stakeholder's group having an appropriate role in the planning and or implementation process (Malcolm, 2017; Falanta and Bengesi, 2018).

At this stage the appropriate role of other stakeholders including corporates to the planning process is to know community priorities presented by the village leaders to the WDC. From these priorities, corporates are able to decide on which one to take as their CSR. The planning process which Kilombero and Mvomero district councils practice does not follow O\&OD planning tool as prescribed in the document "Opportunities and Obstacles to Development - A community participatory planning methodology" (Mefunya, 2011). In the first place, O\& OD put emphasis on involvement of local communities where as the planning practice at ward level in the study areas involve not only local communities but also other stakeholders including Kilombero and Mtibwa sugar companies. 
Table 3: Steps in LGAs Planning Process in the Study Areas

\begin{tabular}{|c|c|c|c|}
\hline STEPS & $\begin{array}{l}\text { KEY INFORMANTS FROM } \\
\text { KILOMBERO AND MVOMERO } \\
\text { DISTRICTS }\end{array}$ & $\begin{array}{lr}\text { KEY INFORMANTS } & \text { FROM } \\
\text { KIDATU } & \text { WARD } \\
\text { (KILOMBERO DISTRICTS) }\end{array}$ & $\begin{array}{l}\text { KEY INFORMANTS FROM } \\
\text { MTIBWA WARD (MVOMERO } \\
\text { DISTRICT) }\end{array}$ \\
\hline 1. & $\begin{array}{l}\text { Informing the village leaders through } \\
\text { Ward Executive Office about the } \\
\text { planning for social service delivery }\end{array}$ & $\begin{array}{l}\text { Leaders and community members } \\
\text { meet and discuss the community } \\
\text { needs at the hamlet level }\end{array}$ & $\begin{array}{l}\text { Village Council identifies needs and } \\
\text { priorities }\end{array}$ \\
\hline 2. & $\begin{array}{l}\text { Identifying needs and priorities by } \\
\text { village assembly }\end{array}$ & $\begin{array}{l}\text { The prioritized needs are presented } \\
\text { to the Village Council by hamlet } \\
\text { leaders }\end{array}$ & $\begin{array}{l}\text { Present the identified needs to the } \\
\text { Village Assembly for discussion }\end{array}$ \\
\hline 3. & $\begin{array}{l}\text { Preparation of village plans by Village } \\
\text { Council following decisions made by } \\
\text { Village Assembly }\end{array}$ & $\begin{array}{l}\text { The Village Council combines the } \\
\text { prioritized needs and prepares } \\
\text { needs and presents them to the } \\
\text { Village Assembly for discussion. }\end{array}$ & $\begin{array}{l}\text { Village Council prepare the Village } \\
\text { plan following decisions from the } \\
\text { Village Assembly }\end{array}$ \\
\hline 4. & $\begin{array}{l}\text { Village leaders presenting the plan to } \\
\text { Ward Development Committee for } \\
\text { technical advice }\end{array}$ & $\begin{array}{l}\text { The Village Assembly discuss and } \\
\text { prioritize the three needs among } \\
\text { those brought to them by Village } \\
\text { Council }\end{array}$ & $\begin{array}{l}\text { Presenting the village plans to the } \\
\text { Ward Development Committee for } \\
\text { technical advice if any }\end{array}$ \\
\hline 5. & $\begin{array}{l}\text { Village Assembly incorporates } \\
\text { technical advice from } \text { Ward } \\
\text { Development Committee }\end{array}$ & $\begin{array}{l}\text { The Village Council prepares the } \\
\text { village development plans and } \\
\text { submits them to the Ward } \\
\text { Development Committee for } \\
\text { technical advice if any }\end{array}$ & $\begin{array}{l}\text { The Ward Development Committee } \\
\text { members and the invited } \\
\text { stakeholders including Mtibwa } \\
\text { Sugar Company discuss and prepare } \\
\text { the Ward development plan using } \\
\text { different village plans }\end{array}$ \\
\hline 6. & $\begin{array}{l}\text { Returning back the plans to Ward } \\
\text { Development Committee for the Ward } \\
\text { to prepare the Ward plan }\end{array}$ & $\begin{array}{l}\text { The Ward Development } \\
\text { Committee members and the } \\
\text { invited stakeholders including } \\
\text { Kilombero Sugar Company discuss } \\
\text { and prepare the Ward plan using } \\
\text { different village plans }\end{array}$ & $\begin{array}{l}\text { Submission of ward development } \\
\text { plans to the District level to be } \\
\text { discussed by District Council }\end{array}$ \\
\hline 7. & $\begin{array}{l}\text { Submission of Ward plan to the } \\
\text { District level to be discussed in the } \\
\text { District Council }\end{array}$ & $\begin{array}{l}\text { Submission of Ward plans to the } \\
\text { District level to be discussed by } \\
\text { District Council }\end{array}$ & $\begin{array}{l}\text { Forward the plan to the Regional } \\
\text { secretariat and national government }\end{array}$ \\
\hline 8. & $\begin{array}{l}\text { Forward the plan to the Regional } \\
\text { secretariat and national government. }\end{array}$ & $\begin{array}{l}\text { Forward the plan to the Regional } \\
\text { secretariat and national government }\end{array}$ & \\
\hline
\end{tabular}

\subsubsection{Engagement of LGAs to corporates Planning Process}

Planning process in sugar companies was examined to reveal how LGAs with legal authority to render social services to communities are involved in the companies CSR execution. Results from key informants' interviews are presented in Table 4:

Results in Table 4 show that, Kilombero and Mtibwa sugar companies had different ways of including LGAs in the planning for social service delivery. Mtibwa Sugar Company invites various LGAs leaders such as WEOs, VEOs, Village chairpersons and ward councilors to the meeting called "Ujirani mwema" (Good neighborhood) in which different community problems are discussed as stipulated in the quote below;

"The company established a forum called "Ujirani mwema" in which leaders from the LGAs and other stakeholders are invited. In this meeting, issues affecting communities including social services and the issues concerning the company are identified. Then in absence of LGAs leaders and other stakeholders, the CEO obtains a list of the community needs and decide on what the company can assist to the community based on the available resources" (Key informant 1, Mtibwa Sugar Company, August, 2015) 
Table 4: Steps for CSR execution in Kilombero and Mtibwa sugar companies

\begin{tabular}{|c|c|c|}
\hline STEPS & MTIBWA SUGAR COMPANY & KILOMBERO SUGAR COMPANY \\
\hline 1 & $\begin{array}{l}\text { Call LGAs leaders (WEOs, VEOs, Village } \\
\text { chairpersons etc.) to Ujiranimwema meeting. }\end{array}$ & $\begin{array}{l}\text { 1. Members of Kilombero Community Charitable Trust } \\
\text { (KCCT) including one members appointed by } \\
\text { Kilombero District Council toObserve the amount of } \\
\text { fund existing in the charity }\end{array}$ \\
\hline 2. & $\begin{array}{l}\text { Discuss the issues affecting communities such as } \\
\text { education, water, electricity, roads and health as } \\
\text { well as the issues affecting the company. }\end{array}$ & $\begin{array}{l}\text { 2. Call for meeting between KCCT members from } \\
\text { Kilombero Sugar Company committee and the } \\
\text { representative from Kilombero District Council. }\end{array}$ \\
\hline 3 & $\begin{array}{l}\text { The chief executive officer (CEO) get the } \\
\text { community needs from the Ujiranimwema meeting }\end{array}$ & $\begin{array}{l}\text { 3. The LGA representative presents the Ward and } \\
\text { village plans to the meeting }\end{array}$ \\
\hline 4 & $\begin{array}{l}\text { In absence of LGA leaders, the CEO decides on } \\
\text { what the company will implement as a CSR }\end{array}$ & $\begin{array}{l}\text { 4. Discussing and prioritizing the presented community } \\
\text { needs by the member of the trustee }\end{array}$ \\
\hline 5 & Implementing CSR activities to the chosen place & $\begin{array}{l}\text { 5. Comparing the prioritized needs with the available } \\
\text { resource in the trust fund }\end{array}$ \\
\hline 6 & NA & $\begin{array}{l}\text { 6. Deciding on the project and the place (village) to } \\
\text { assist }\end{array}$ \\
\hline 7 & NA & 7. Implementation of Corporate Social Responsibility \\
\hline
\end{tabular}

The above quote implies that the planning process in Mtibwa Sugar Company is inclusive because LGAs leaders are involved in the discussion of problems facing communities. Inviting the local leaders to the meeting creates friendship between the company and the LGAs which assures safety of the company. The planning process agrees with inclusiveness aspect of Communicative Planning Theory which affirms that, the planning is inclusive if it involves broad range of stakeholders (Elliot, 2014). However, discussion in the Ujirani mwema forum is not confined to community priorities only but also includes all problems facing surrounding communities. For that reason, there is a possibility for the company to implement a social service which is not among the community's priorities.

Similarly, it was reported from Kilombero Sugar Company that,

"The Company reserved 2000 hectare in which any benefit results from it is used to assist the surrounding communities. In accomplishing this, the company established the trust fund "Kilombero Community Charitable Trust (KCCT)". Kilombero district council has a representative in this trust. The district officer with the list of the community priorities at hand and the other three members from the company discuss the community priorities presented by the division officer and decide on the village and services to assist based on the profit gained" (Key informant 2, Kilombero Sugar Company, September, 2015).

This implies that the planning for CSR execution in Kilombero Sugar Company is also inclusive because it involves the LGA through its representative to the planning process. Healy et al. (2014) accentuate that in inclusiveness, people who are affected by the plan have the opportunity to be involved in the planning process. Including stakeholders to the planning for social service delivery creates a sense of ownership (Falanta and Bengesi, 2018; Litman, 2013).

\subsubsection{Openness of LGAs Planning Process to Corporates}

The openness of stakeholders in making decision and agreeing on the social services to be provided to communities during the planning process reveals transparency in the planning. In this paper, transparency was revealed by the community members who openly discussed, decided and agreed on the community priorities which were later combined to make village development plans. It was revealed during FGD at Madizini village in Mtibwa Ward that copies of the village development plans which are submitted to the ward level are also shared to different stakeholders including Mtibwa Sugar Company for them to assist the surrounding communities based on their priorities. Transparency is also marked when sugar companies openly exchange their knowledge and views with LGAs leaders and other stakeholders who are invited to attend the WDC during planning process. This is because the stakeholders have the right to provide their ideas and advices on the issues discussed at the WDC. Thus, through advices stakeholders including corporates may influence decision making on the kind of social service to be delivered to communities. According to Agger and Lo"fgren, (2008) all actors have a right of access to the information on which the planning decision is to be based; the right to contest the views of others and influence the decision-making process and the outcome. Moreover, openness among LGAs and other stakeholders on the community priorities during planning process provides opportunity for stakeholders to decide on the service to be provided during CSR execution. According to Muhammad et al (2015), stakeholders should 
understand how the planning process operates. The result is also supporting CPT, which states that the planning is transparency when it is open to all stakeholders (Johnston, 2002).

However, the planning process in LGAs particularly at Ward level where development stakeholders including sugar companies are involved do not incorporate activities to be supported through CSR. The WDC plan lacks CSR inputs because representatives of companies do not hold decision making authority. Furthermore, it was found that the WDC planning precedes that of companies for CSR; hence, there is misalignment of planning seasons between the LGAs and corporates leading to double allocation of resources for some social services. Therefore, there is a need for budget review by the LGA to relocate resources that corporates use to support community activities.

\subsubsection{Openness of corporates Planning Process to LGAs}

The sharing of ideas and openness to stakeholders during planning process reveals transparency in the planning. The results in Table 4 indicate that there is no transparency in Mtibwa Sugar Company planning process because the LGA leaders are not aware of the company's plans for CSR. This is because LGA leaders are not involved in making decision and agreement on the social service to be delivered to their communities. Instead, the CEO decides on the social service to deliver through CSR in the absence of LGA leaders. This may result in duplication of social services which translate into wastage of resources because the company can direct resources to the social services in which the LGAs have already invested and vice versa. However, literature emphasizes that stakeholders should be involved to the planning process and understands how key decisions are arrived (Agba et al., 2013; Falanta \& Bengesi, 2018; Muhamad et al., 2015).

On the other hand, the planning process for social service delivery in Kilombero Sugar Company is transparent. First, community priorities are presented during the KCCT meeting by LGA representative. This ensures that selection of CSR activity by the company is based on community priorities presented. Also, planning decisions are made by both, LGAs representatives and their counterpart from the company. This transparency enables LGAs to allocate resources to other services which are not funded by other development partners including sugar companies.

\subsubsection{Outcome of inclusiveness and transparency in the planning process}

According to CPT, inclusiveness and transparency are core components to the planning process (Healey, 2006). The planning can be inclusive but not transparency. When this happen, LGA or company may implement the project which is not among the priorities of the local communities but also the project may not be acknowledged by the stakeholders. For example, it was mentioned during an interview that:

"The company constructed a road worth 700,000,000/=Tshs in 1998" (key informant 1, Mtibwa Sugar Company, August, 2015). This road was not LGAs priority by then.

This is revealed during the key informant interview with the key informant in Mvomero district council who confirmed the existence of the road but upholds that the road is for the company's use (private). It was reported that the road passes within the company's farms, therefore, if any person needs to use the road has to get access permit from the company security guard at the entrance gate. In this regard as pointed out during the interview, the road constructed by Mtibwa Sugar Company is not recognized as among CSR activities by Mvomero district council. This is because, although the project was implemented as community social service, its construction plan lacked transparency to the LGA. This observation is consistent with CPT which suggests that transparency in planning is central to achieving legitimacy/acceptability and trust in any planning system (Elliott, 2014). Hence, lack of transparency in the planning process by Mtibwa Sugar Company resulted into failure of Mvomero district council to accept the service despite huge investment done by the company. Lack of acknowledgement of Mvomero district council for the constructed road, despite being accessible and available for use by both the company and community members, demonstrates the strength of CPT in guiding the planning process. Moreover, failure to recognize the efforts of corporates could be detrimental to the government and communities i.e. there will be spending of unaccountable resources by the government that could lead to duplication of efforts towards social service delivery and eventually translate to wastage of resources.

On the other hand, when the planning is inclusive and transparent, it leads to resource diversification. For example, it was reported that: 
“... Kilombero district council prepared a budget of 40,000,000/= Tshs for building patient wards at Nyandeo health center in Mkamba village in Kidatu Ward. After being informed that Kilombero Sugar Company was planning to build the Wards to the same health center, the District Council reallocated the money through special councilors meeting to build a laundry to the same health center" (Key informant 3, Kidatu Ward, September, 2015).

The above data suggest that transparency in Kilombero Sugar Company planning process has resulted into improving the nature of social service delivery; in particular the efficiency use of resources and diversification of social services. The data also reveals that, although transparency was observed in Kilombero Sugar Company, there were different time of planning for social service delivery between Kilombero District Council and other development stakeholders including Kilombero Sugar Company. That is why Kilombero District Council had allocated resources without knowing what the company had planned to support communities through CSR. This resulted into over using of resources in conducting a special councilors meeting to reallocate the resources. Therefore, it is important for the WDC to communicate their plans, including decisions from various development stakeholders regarding social services they plan to provide as CSR, to district council in time. Such interface enables LGAs to allocate resources to other priorities which are not covered by other development stakeholders.

\subsection{Conclusions and recommendations}

\subsection{Conclusions}

The study concludes that planning process in LGAs is in line with CPT which indicates that inclusiveness and transparency are the core components in planning process and they are associated with successful outcomes. This is because various stakeholders including corporates and community members and their leaders from hamlet to ward level were involved in preparing village and ward development plans. LGAs and corporates in the study area have disharmonized phases of planning for social service delivery as results companies' plans are not included to the Ward development Plans. CSR activities performed by companies are reported to the district council by government official during their quarterly reports and through Ward Executive Officer after receiving the information from the subordinates. The paper also concludes that the current planning process at the LGAs is different from what is stipulated in the O\&OD. While the O\&OD focuses only on community involvement, the actual planning includes both the community and other stakeholders. Hence there are positive components including involving other development stakeholders to the current planning process for social service delivery which can be picked to strength the O\&OD. The Mtibwa Sugar planning process was not transparent because the LGAs leaders were not involved in deciding on the social service to be delivered to their communities. On the other hand, Kilombero Sugar Company's planning process was transparent because the LGA representatives were involved in the planning process and community priorities were considered through their representatives. The findings further revealed misalignment of planning seasons between the LGAs and corporates leading to double allocation of resources for some social services.

\subsection{Recommendations}

The current planning for social service delivery involves community members and other development stakeholders including sugar companies. Therefore, the study recommends that the aspect of involving other development stakeholders which is missing in the O\&OD participatory tool be included. This will make the tool to be in line with CPT which asserts that inclusiveness (range of stakeholders involved in the planning process) and transparency (stakeholders involved in decision making) are core components of planning process. The study further recommends that there should be budget review by the LGA to relocate resources that corporates use to support community activities.

The study shows that LGAs and corporates in the study area have their own ways of communicating to each other when planning for social service delivery. In this case, there is a need to conduct study on resource complementarity for social service delivery between LGAs and corporates in the study area. This will help to show how resources are utilized in providing social services to communities in the study area without duplicating efforts. 


\section{References}

Abdulillah, A., Yacoob, M.R., Ismail, M. \& Zakaria, M.N. (2017). Corporate Engagement with the Community: Building Relationships through CSR. Journal of Engineering and Applied Sciences, 12, 1538 - 1542. DOI: 10.3923/jeasci.2017.1538.1542

Agba, M. S., Akwara, A.F. \& Idu, A. (2013). "Local Government and Social Service Delivery in Nigeria: A Content Analysis." Academic Journal of Interdisciplinary Studies, 2, 455-462. DOI: 10.5901/ajis.2013.v2n2p455

Aguinis, H. \& Glavas, A. (2012). What We Know and Don't Know About Corporate Social Responsibility: A Review and Research Agenda. Journal of Management, 38, 932 - 968. DOI: 10.1177/0149206311436079

Baxter, P. \& Jack, S. (2008). Qualitative Case Study Methodology: Study Design and Implementation for Novice Researchers. The Qualitative Report,13, 544-559.

Bengesi, K. M. K. (2014). Assessing Impact of Biofuel Investments on Local Livelihoods in Tanzania: A case of Kisarawe, Bagamoyo and Kilwa Districts. Retrieved October 15, 2018, from http://www.mviwata.org/wpcontent/uploads/2014/09/Study-Report-on-Biofuel-Investments-July2012.pdf

Bengesi, K. M. K., Msuya, C. P., Salanga, R., \& Mwakalobo, S. (2009). Implication of Biofuel Production on Food Security in Tanzania. Retrieved May 2, 2018, from http://www.actionaid.org/sites/files/actionaid/implication_of_biofuels_production_on_food_security_in_tan zania.pdf

Bengesi, K.M.K., \& Abdalla, J.O. (2018). Forces Driving Purchasing Behaviour of Tourists Hotels along TouristAgricultural Supply Chain in Zanzibar, International Journal of Marketing Studies, 10(2):36-46.

Bengesi, K.M.K., Mwesiga, P., \& Mrema, T. (2016). Public Private Partnership in Tanzania's Transportation Infrastructure: The way PPP is Understood, Challenges and the way Forward [Online] Available at http://esrf.or.tz/docs/PPP2016.pdf . Date accessed 12 November 2017

Bolatito, S. \& Ibrahim, S. D. (2012). Challenges of Local Government Administration in Nigeria; An Appraisal of Nigerian Experience. International Journal of Science and Research (IJSR), 3, $562-568$.

Carroll, A.B \& Shabana, K.M. (2010). The Business Case for Corporate Social Responsibility: A Review of Concepts, Research and Practice. International Journal of Management Reviews, 85 - 105. https://doi.org/10.1111/j.1468-2370.2009.00275.x

Chirenje, L.I., Giliba, R.A. \& Musamba, E. B. (2013). Local communities' participation in decision-making processes through planning and budgeting in African countries. Chinese. Journal of Population Resources and Environment, 11, 1 - 10. https://www.tandfonline.com/doi/abs/10.1080/10042857.2013.777198

Carlitz, R. (2013). Improving Transparency and Accountability in the Budget Process: An Assessment of Recent Initiatives. $\quad$ Development Policy Review, https://onlinelibrary.wiley.com/doi/abs/10.1111/dpr.12019

Ejue, E.A. \& Madubueze, M. C. (2014). Corruption and Service Delivery in Local Government System in Nigeria: A Content Analysis. International Journal of Business and Social Science, 10, 98 - 107

Elliott, M. (2014). History and Theories of Planning [Online] available: https://georgiaplanning.org/.../AICP.../2014_AICP_Exam_Prep_Theory_History.pdf (April 3, 2018).

Falanta, E.M., \& Bengesi, K.M.K. (2018). Drivers and Consequences of Recurrent Conflicts between Farmers and Pastoralists in Kilosa and Mvomero Districts, Tanzania. Journal of Sustainable Development, 11(4):1326.

Fjeldstad, O., Katera, L. \& Ngalewa, E. (2010). Planning in Local Government Authorities in Tanzania: Bottomup Meets Top-down. Research on Poverty Alleviation (REPOA), 18, 1-8.

Healy, S., B.S., Ewing, M., Keane, L., Garvey, D., Carr, S., Hanan, R. \& McLaughlin, S. (2014). Working Group Report on Citizen Engagement with Local Government. Department of the Environment, Community and Local Government. [Online] available: www.aph.gov.au/About_Parliament/...Library/.../12rp01 (June 16, 2016).

Healey, P. (2006). Collaborative Planning: Shaping Spaces in Fragmented Societies. MacMillan. London.[Online] available: https://www.amazon.com/Collaborative-Planning-Shaping-FragmentedSocieties/.../07... (April 2, 2018).

Henjewele, F., Mwambe, G., Ngalewa, E. \&Nygaard, K. (2004). Local Government Finances and Financial Management in Tanzania. Special Paper No. 16.Mkuki na Nyota Publishers, Dar es Salaam, Tanzania. 
Hohnen, P. (March, 2007). Corporate social responsibility: implementation guide for business. [Online] available: http://www.iisd.org/pdf/2007/csr_guide.pdf (April 28, 2016).

Hollyer, J. R., Rosendorff, B. P., \& Vreeland, J. R. (2011). Democracy and transparency. Journal of Politics, 73, 1191-1205. http://dx.doi.org/10.2139/ssrn.1750824

Iravo, M. A. \& Nzulwa, J. D. (2015). Analysis of the relationship between devolved governance, political decentralization, and service delivery: A critical review of literature. European Scientific Journal 11, 457 472

Johnston, M, \& Sahr J. (2002). Building a Clean Machine: Anti-Corruption Coalitions and Sustainable Reforms, World Bank Institute Working Paper number 37208 (December).

Kanji, R. \& Agrawal, R. (2016). Models of Corporate Social Responsibility: Comparison, Evolution and Convergence. IIM Kozhikode Society \& Management Review,5, 141-155. journals.sagepub.com/doi/abs/10.1177/2277975216634478

Komba. A., Bengesi, K.M.K., \& Mwageni, T. (2018). Planning: Concepts, Theories and Models. In: C. Lifuliro., I. Zilihona., T. Mdendemi., A. Kamanzi., G. Kinyashi, T. van Dijk, ed., Tanzania Planners' Handbook: A Guide for Development Planning, $2^{\text {nd }}$ ed. Leiden: African Studies Centre Leiden, The Netherlands.[Online] Available:

https://scholar.google.com/scholar?hl=en\&as_sdt=0\%2C5\&q=Komba+and+Bengesi+publication\&btnG= (March 12, 2018).

Litman, T. A. (2013). Planning Principles and Practices. [Online] available: http://www.vtpi.org/planning.pdf (July 18, 2017)

Lunyelele, S.P., Bengesi, K.M.K., \& Katani, J.Z. (2016). Awareness of Peri-Urban Farmers on the Concept of Climate Change: A Case of Temeke District, Dar es salaam Region. Journal of Environment and Earth Science, 6 (7):24-34.

Lunyelele, S.P., Katani, J.Z., \& Bengesi, K.M.K. (2016). Mitigation and Adaptation Measures of Peri-Urban Farmers as a Response to Climate Change in Temeke District, Dar es Salaam Region. Journal of Agriculture and Environmental Sciences, 7(1):40-52

Malcolm, J. (2017). Contested meanings of inclusiveness, accountability and transparency in trade policy making. Internet Policy Review,6, DOI: 10.14763/2017.4.772.

Maliganya, W., \& Bengesi, K.M.K. (2018). Policy Enabling Environment of Mining Sector in Tanzania: A Review of Opportunities and Challenges. Journal of Sustainable Development, 11(4):1-12.

Muhammad, Z., Masron, T. \& Majid, A. A. (2015). Local Government Service Efficiency: Public Participation Matters. International Journal of Social Science and Humanity, 5, $827 \quad-\quad 831$. https://doi.org/10.1016/j.sbspro.2015.11.067

Mukhopadhyay, C. (2017). Transparency in Planning Practice: Contemporary urban reform in India. Italian Journal of Planning Practice, 7, 213 - 233.

Mefunya, G. F. (2011). The opportunities and obstacles to development planning method used in Tanzania's decentralized local governments: A case of Rulenge and Murusagamba Wards in Ngara District of Kagera Region. [Online] available: http://hdl.handle.net/10570/3560 (February 27, 2018)

O'riordan, L. \& Fairbrass, J. (2014). Managing CSR stakeholder engagement: A new conceptual framework. Journal of Business Ethics, 125, 121-145.

Revathy, B. (2012). Corporate Social Responsibility - An Implementation Guide for Business. Far East Journal of Psychology and Business, 6, 15 - 31

Ringold, D., Holla, A., Koziol, M. \&Srinivasan, S. (2012). Citizens and Service Delivery: Assessing the Use of Social Accountability Approaches in the Human Development Sectors. The World Bank, Washington, DC

Safkaur, O. (2016). Corporate Social Responsibility in The Health Sector for Papua Indonesia. International Journal of Science \& Technology research, 5, 159- 167.

Smith, E. (2008). The CSR Implementation process: A four-step model to an efficient Corporate Social Responsibility (CSR) implementation. [Online] available: http://www.divaportal.org/smash/get/diva2:231292/FULLTEXT01.pdf (January 9, 2017)

Starman, A. B. (2013). The case study as a type of qualitative research. Journal of Contemporary Educational Studies 1,28

Weston, J \& Weston, M. (2013). Inclusion and Transparency in Planning Decision-Making: Planning Officer Reports to the Planning Committee, Planning Practice \& Research, 28, 186-203. 